\title{
Figurative Language and Rhetoric Structure in Tetralogy of Laskar Pelangi by Andrea Hirata
}

\author{
Dorra Paramita Kusuma Wardani $1^{1}{ }^{*}$ Anwar Efendi ${ }^{1}$
}

\author{
${ }^{I}$ Indonesian Language and Literature Education Study Program, Universitas Negeri Yogyakarta, Yogyakarta, Indonesia \\ *Email:dorra_paramita2016@yahoo.com
}

\begin{abstract}
Figurative language and rhetoric structure in tetralogy of Laskar Pelangi by Andrea Hirata could be used as the alternative materials of Indonesian Language subject at the twelfth grade of Vocational School. This research was descriptive qualitative research. The data resource was tetralogy of Laskar Pelangi by Andrea Hirata such as the Laskar Pelangi novel, Sang Pemimpi novel, Edensor novel, and Maryamah Karpov novel. The collecting data technique that was used was reading and taking note or library research. The data validation contained of validity and reliability test. The data was described by using content analysis technique. The results of the research were, as follows. First, the figurative languages that were contained in tetralogy of Laskar Pelangi by Andrea Hirata consisted of two figures of speech such as comparing and relating. The genres of the comparingfigure of speech that were found were simile, metaphor, personification, and allegory whereas the genres of the relating figure of speech were metonymy and synecdoche. Besides, the rhetoric structures contained in tetralogy of Laskar Pelangi were repetition, contrast, and other structures. Genres of repetition were the repetition, parallelism, polysyndeton, and asyndeton thus the genres of contrast structure were hyperbola, litotes, paradox and irony. Other structures that were found were rhetoric, climax, anti-climax and antithesis. Based on the data that was analyzed, there were many simile styles. Second, the figurative languages and rhetoric structures in the tetralogy had different functions, so when they were collaborated into one, it would produce a gorgeous work. The function of the figurative languages and rhetoric structures in the tetralogy of Laskar Pelangi was the enrichment of language style that had high quality and quantity, so they could create the esthetic values toward Andrea Hirata's work. Third, based on the identification results of genre and function of figurative language and rhetoric structure in tetralogy of Laskar Pelangi could be implemented for the materials of novel texts in Indonesian language subject for the twelfth grade students of Vocational School.
\end{abstract}

Keywords: Figurative language, Rhetoric structure, Novel

\section{INTRODUCTION}

A literature work was a thought result of the authors that was created into fiction story or sometimes contained of life story. The literature work was served for the reader to be enjoyed. By literature work, the authors could express their ideas into various themes of the stories and one of them was about education. Through the literature works, the authors wanted to show the essential and meaning of life to the readers. Style is the writer's choice of employing certain structure over others which are available in the language. It means choosing to say an idea in a particular form when it could be said in another, more readily understandable way [1].

After Laskar Pelangi novel released at 2005 and got good response from the readers, at 2006 the novel of Sang Pemimpi released, Edensor novel then released at 2007, and as the last of the tetralogy of Laskar Pelangi, Maryamah Karpov novel, released at 2008. Andrea Hirata expressed his ideas into the tetralogy of Laskar Pelangi by using unique languages and styles. As language as a medium of communication as well as a means of shaping one's thoughts, style is viewed as the correspondence between thought and expression [2]. A 
writer's choice of language is an attempt to reveal artistic principle [3].

The tetralogy be able to trigger the readers' inspiration and motivation even by intention, spirit, effort, diligence, and praying, what we wanted we would get it. It was also stated by Sapardi Joko Damono as a litterateur and professor of Culture Science Faculty of Indonesia University in the appreciation page of Laskar Pelangi [4]. Stylistics is a methodology which takes into consideration the reader's personal and social context [5].

Stylistics is the study of the devices in language such as rhetorical terms and syntactical devices that are taken to produce expressive or literary style [6]. Based on the explanation above, the researchers focused on the figurative languages and rhetoric structures as the linguistic study. The theory that was used as the research theory was stylistic theory in which this research could be used as the alternative materials for Indonesia language subject for the twelfth grade students of Vocational School. Describing the genres of figurative languages and rhetoric structures in tetralogy of Laskar Pelangi used grouping method by Nurgiyantoro [7].

Besides, stylistics was a subject that made a literature work as the research object. Stylistics is a branch of linguistic study focused on analyzing how author expresses his/her own in his/her own literary text(s). Stylistics is the branch of genera linguistics which focuses on style (i.e. the specific way a particular writer or speaker expresses himself), particularly in works of literature [8].

Ferdows and Masoud tried to express the importance of linguistic style analysis on literary research - how analysis of linguistic style analysis is detrimental to unravel the encoded meaning of literary text(s) and its structural features. The analysis proposed in this study was by identifying the linguistic patterns and its designated functions in the respective literary text. Ferdows Aghagolzade \& Masoud Dehghan's journal was mainly focused on understanding the linguistic style and its application in poems [9].

Stylistics analysis is the analysis of various language styles to extract the meaning or massage contained in texts [10]. Stylistic analysis is commonly utilized to explain the linguistic relation between artistic function and its actual meaning of the literature in context. Linguistic stylistics regards language from the perspective of the subjectivity that embellisher its use [11].. This stylistic explanation will delve deeper into the richness of linguistic forms commanded, such as the pronunciation, lexical, grammatical, figurative usages, rhetorical, and even the graphology of the respective literature [7]. Stylistic analysis has been used to provide linguistic evidence for interpretation of a literary work [12].

\section{DESCRIPTION OF RESEARCH RESULT}

\subsection{The Genres of Figurative Language and Rhetoric Structure in Tetralogy of Laskar Pelangi by Andrea Hirata}

The tetralogy of Laskar Pelangi by Andrea Hirata was the literature work of the children of the nation that had abundant figurative languages and rhetoric structures. It was proved by founding data about figurative languages and rhetoric structures inside it.

The genres of figurative languages were comparing figure of speech and relating figure of speech. The genres of comparing figure of speech that were found were simile, metaphor, personification, and allegory whereas the genres of relating figure of speech were metonymy and synecdoche.

Moreover, the genre of the rhetoric structures was the strategic structure that consisted of three groups. These were repetition, contrast, and other structures. Genres of repetition were the repetition, parallelism, polysyndeton, and asyndeton thus the genres of contrast structure were hyperbola, litotes, paradox and irony. Other structures that were found were rhetoric, climax, anti-climax and antithesis [4].

\subsection{The Functions of Figurative Language and Rhetoric Structure in Tetralogy of Laskar Pelangi by Andrea Hirata}

Based on the research results of the tetralogy of Laskar Pelangi by Andrea Hirata could be gotten the functions of the figurative language, as follows.

Table 1.

The Functions of the Figurative Language in Tetralogy of Laskar Pelangi by Andrea Hirata

\begin{tabular}{|l|l|l|}
\hline No & \multicolumn{1}{|c|}{$\begin{array}{c}\text { Figurative } \\
\text { Language }\end{array}$} & \multicolumn{1}{c|}{ Function } \\
\hline \multirow{2}{*}{1.} & Comparing figure of speech \\
\cline { 2 - 3 } & Simile & $\begin{array}{l}\text { The media to draw the } \\
\text { characters, to make the story }\end{array}$ \\
\hline
\end{tabular}




\begin{tabular}{|c|c|c|}
\hline & & $\begin{array}{l}\text { and backgroud more alive and } \\
\text { to create the harmony and } \\
\text { cohesiveness of the story. }\end{array}$ \\
\hline & Metaphor & $\begin{array}{l}\text { The media to draw the events } \\
\text { and the characters' situation } \\
\text { in the story. }\end{array}$ \\
\hline & Personification & $\begin{array}{l}\text { The media to make the } \\
\text { background more alive to get } \\
\text { the imagination and trigger } \\
\text { other certain senses } \\
\text { impression. }\end{array}$ \\
\hline & Allegory & $\begin{array}{l}\text { The media to give colour, to } \\
\text { create aesthethics values, to } \\
\text { describe and make it real, and } \\
\text { to emphasize the content of } \\
\text { the story so the reader could } \\
\text { understand the story correctly. }\end{array}$ \\
\hline 2. & Relating figure & of speech \\
\hline & Metonymy & $\begin{array}{l}\text { To strengthen the certain } \\
\text { name or merk that were } \\
\text { influential for the characters, } \\
\text { to make the story more alive, } \\
\text { and to produce the real } \\
\text { imagination since the story } \\
\text { told by the author was around } \\
\text { readers. }\end{array}$ \\
\hline & Synecdoche & $\begin{array}{l}\text { To strengthen the characters' } \\
\text { reaction toward the events } \\
\text { faced and to appear the } \\
\text { imagination. }\end{array}$ \\
\hline
\end{tabular}

Besides, based on the research results of the tetralogy of Laskar Pelangi by Andrea Hirata could be gotten the functions of the rhetoric structure, as follows.

Table 2.

The Functions of the Rhetoric Structure in Tetralogy of Laskar Pelangi by Andrea Hirata

\begin{tabular}{|c|l|l|}
\hline No & $\begin{array}{c}\text { Rhetoric } \\
\text { Structure }\end{array}$ & \multicolumn{1}{c|}{ Function } \\
\hline \multirow{2}{*}{1.} & Repetition \\
\cline { 2 - 3 } & Repetition & $\begin{array}{l}\text { To strengthen the events through } \\
\text { emphasizing, confirming, and } \\
\text { beutifying the story and to show } \\
\text { the wanted meaning to the reader } \\
\text { by repearing the words or group } \\
\text { of words. }\end{array}$ \\
\hline
\end{tabular}

\begin{tabular}{|c|c|c|}
\hline & Parallelism & $\begin{array}{l}\text { To strengthen the events through } \\
\text { emphasizing, confirming, and } \\
\text { beutifying the story and to show } \\
\text { the wanted meaning to the reader } \\
\text { by repearing the words or group } \\
\text { of words. }\end{array}$ \\
\hline & $\begin{array}{l}\text { Polysyndet } \\
\text { on }\end{array}$ & $\begin{array}{l}\text { To emphasize and focus on the } \\
\text { utterance through using } \\
\text { command words. }\end{array}$ \\
\hline & Asyndeton & $\begin{array}{l}\text { To emphasize and focus on the } \\
\text { utterance through repeating the } \\
\text { punctuation to show the equal } \\
\text { position }\end{array}$ \\
\hline \multirow[t]{5}{*}{2.} & \multicolumn{2}{|l|}{ Contrast } \\
\hline & Hyperbola & $\begin{array}{l}\text { To emphasize on the intensive } \\
\text { meaning that wanted to be } \\
\text { expressed by using the excessive } \\
\text { ways to make it looked like real, } \\
\text { so it could raise the imagination } \\
\text { and certain senses. }\end{array}$ \\
\hline & Litotes & $\begin{array}{l}\text { To emphasize on the intensive } \\
\text { meaning that wanted to be } \\
\text { expressed by understating the } \\
\text { fact to have a modest attitude and } \\
\text { keep the well manner. }\end{array}$ \\
\hline & Paradox & $\begin{array}{l}\text { To make the problems in the } \\
\text { story more interesting by } \\
\text { choosing the correct language } \\
\text { and expression that could present } \\
\text { the aesthetic effect. }\end{array}$ \\
\hline & Irony & $\begin{array}{l}\text { To criticize and tease the } \\
\text { characters' attitude softly to } \\
\text { create uncommon senses. }\end{array}$ \\
\hline \multirow[t]{5}{*}{3.} & \multicolumn{2}{|c|}{ Other Structures } \\
\hline & $\begin{array}{l}\text { Rhetorics } \\
\text { questions }\end{array}$ & $\begin{array}{l}\text { To raise the rhetoric effects that } \\
\text { could involve the reader or } \\
\text { listener in rational and emotional. }\end{array}$ \\
\hline & Climax & $\begin{array}{l}\text { To express and emphasize the } \\
\text { idea by showing the increasing of } \\
\text { the intensity of the climax and } \\
\text { important } \\
\text { chronologically. }\end{array}$ \\
\hline & $\begin{array}{l}\text { Anti- } \\
\text { climax }\end{array}$ & $\begin{array}{l}\text { To express and emphasize the } \\
\text { idea by showing the decreasing } \\
\text { of the intensity of the climax and } \\
\text { important } \\
\text { chronologically. }\end{array}$ \\
\hline & Antithesis & $\begin{array}{l}\text { To strengthen the events through } \\
\text { emphasizing, confirming, and }\end{array}$ \\
\hline
\end{tabular}




\begin{tabular}{|l|l|}
\hline & $\begin{array}{l}\text { beutifying the story by showing } \\
\text { the opposite meaning of the } \\
\text { words to create the aesthetics } \\
\text { values. }\end{array}$ \\
\hline
\end{tabular}

2.3 The Implementation of Figurative Language and Rhetoric Structure in Tetralogy of Laskar Pelangi by Andrea Hirata as the Alternative Materials of Indonesian Language Subjects at the Twelfth Grade Students of Vocational School

Stylistics is a strong tool that can be used in the classroom in the teaching of the text [13]. In the educational level of Vocational School, the explanation about the language style in novel contained in the twelfth grade materials. Based on the mapping materials, the figurative language and rhetoric structure in the tetralogy of Laskar Pelangi by Andrea Hirata could be implemented on the fifth theme in novel text that was stated in Basic Competence 3.1 as "understanding the structure and the rules of novel texts in oral and written form".

\section{DISCUSSION}

Based on the description of research result above, this part consisted of three parts that were the genre, function and implementation of figurative languages and rhetoric structures in tetralogy of Laskar Pelangi by Andrea Hirata as the alternative materials for the Indonesian Language subject of the twelfth grade of Vocational School. Thus, they would be explained further.

\subsection{The Genres of Figurative Language and Rhetoric Structure in Tetralogy of Laskar Pelangi by Andrea Hirata}

The analysis that was done from the tetralogy of Laskar Pelangi by Andrea Hirata showed some results. The genres of figurative languages that were found in tetralogy novel were the comparing figure of speech and relating figure of speech. The genres of comparing figure of speech that were found were simile, metaphor, personification, and allegory whereas the genres of relating figure of speech were metonymy and synecdoche.

Therefore, the genres of the rhetoric structures were repetition, parallelism, polysyndeton, asyndeton, hyperbola, litotes, paradox and irony, rhetoric question, climax, anti-climax and antithesis. The figurative language that can be found in the Laskar Pelangi tetralogy can be seen in the following table.

Table 3. The Recapitulation of Figurative Language in Tetralogy of Laskar Pelangi by Andrea Hirata

\begin{tabular}{|l|c|}
\hline $\begin{array}{c}\text { The Genres of Figurative } \\
\text { Language }\end{array}$ & Amount of Data \\
\hline \multicolumn{2}{|c|}{ Comparing Figure of Speech } \\
\hline a. Simile & 1176 \\
\hline b. Metanhor & 139 \\
\hline c. Personification & 461 \\
\hline d. Allegorv & 105 \\
\hline \multicolumn{2}{|c|}{ Relating Figure of Speech } \\
\hline a. Metonvmv & 142 \\
\hline b. Svnecdoche & 13 \\
\hline
\end{tabular}

Based on the table above, it showed that simile was the figure of speech that had highest number and synecdoche became the figure of speech with lowest number.

\subsection{The Functions of Figurative Language and Rhetoric Structure in Tetralogy of Laskar Pelangi by Andrea Hirata}

The figurative language and rhetoric structure in tetralogy of Laskar Pelangi by Andrea Hirata had different functions, so when they were collaborated into one, they would produce a beautiful literature work. Simile could draw the characters to make the story and background more alive, and created the harmony and cohesiveness of the story. Metaphor had a function to emerge new vocabulary, for example, Simpai Keramat that meant as loneliness. Besides, this figure of speech also used to draw the events and the characters' situation in the story. Thus, the personification made the background more alive to get the imagination and triggered other certain senses impression whereas the allegory gave colour, created aesthethics values, described and made the language real, and emphasized the content of the story so the reader could understand the story correctly.

Besides, the metonymy aimed to strengthen the certain name or merk that were influential for the characters, to make the story more alive, and to produce the real imagination since the story told by the author might be similar with the readers' environment. The 
synecdoche had the function to strengthen the characters' reaction toward the events faced and emerged the imagination.

Moreover, the repetition could strengthen the events through stressing, confirming, and beautifying the story by emphasizing the meaning that wanted to be expressed to the reader by repeating the words or group of words. Parallelism also gave the similar contribution as the repetition did. Thus the polysyndeton got the role to emphasize and focus on the utterance through using command words whereas asyndeton also emohasized and focused on the utterance through repeating the punctuation to show the equal position.

Afterwards, hyperbola could emphasize the intensive meaning that wanted to be expressed by using the excessive ways to make the expression look like real, so it could raise the imagination and certain senses. Litotes emphasized on the intensive meaning that wanted to be expressed by understating the fact to have a modest attitude and kept the well manner in relationship. Thus, paradox made the problems in the story more interesting by choosing the correct language and expression to present the aesthetic effect. Irony was used to criticize and tease the characters' attitude softly to create the effects from uncommon senses.

The rhetoric questions could emerge the rhetoric effects and involved the reader or listener whether rational and emotional. Climax was used to express and emphasize the idea by showing the increasing of the intensity of the climax and important events chronologically whereas the anti-climax was used to express and emphasize the idea by showing the decreasing of the intensity of the climax and important events chronologically. Antithesis strengthened the events through emphasizing, confirming, and beutifying the story by showing the opposite meaning of the words to create the aesthetics values.

The functions of figurative language and rhetoric structure in tetralogy of Laskar Pelangi were the enrichment of figure of speech that had quality and quantity. They would be able to create the aesthetics values in Andrea Hirata's works. Based on the explanation of the funtions, it could be concluded that Andrea Hirata could draw the real life of the characters through his expression. By using the figurative language and rhetoric structure, the expressing of meaning was more impressing, more alive, had more quantity, more clear, and more interesting than the others.

Founding of figurative language and rhetoric structure in tetralogy of Laskar Pelangi, it proved that these novels contained of the beautiful languages and expressions. They could not be separated from the meaning that wanted to be expressed by the author. The using of figurative language and rhetoric structure was the media to get the meaningful effects from the texts. Expressing language in literature reflected the author's attitude and feeling that aimed to influence the readers' attitude and feeling too. Through figurative language and rhetoric structure that were expressed in certain ways aimed to convince, to change the opinion, to emerge the sympathy, empathy or antiphaty and other feelings that showess the existence of the strength of language. The rhetoric aspects were needed to produce the rhetoric language through the using of its style.

\subsection{The Implementation of Figurative Language and Rhetoric Structure in Tetralogy of Laskar Pelangi by Andrea Hirata as the Alternative Materials of Indonesian Language Subjects at the Twelfth Grade Students of Vocational School}

The scope of the Indonesian literature materials in Vocational School existed in Indonesian Language subject. There were some reasons why the researchers chose the figurative language and rhetoric structurein tetralogy of Laskar Pelangi by Andrea Hirata as the subject to be analysed. Besides, the reasons also related to these materials that could be implemented as the alternative materials for the twelfth grade students of Vocational School. The learning goals that consisted on the Core Competence of Indonesian Language subject of Vocational School required the media in teaching and learning materials, and one of them was the literature work such as novel. The tetralogy of Laskar Pelangi could be an inspiration and motivation for the students to struggle to achieve their aspiration or desire. The content of this tetralogy could be the example for them to be more enthusiasm and had an effort to achieve their willing although they had many lacks. They had to believe that they could be success and whether it would be success or not in the future, they must believe that they must have faith to their God and themselves. It was also shown in the story in which the successful of Arai and Ikal to study abroad. The novel that had best quality was actually correct if it could be implemented in teaching and learning process since the novel could tell the characters as the good lesson for the students.

The interview that was done by the researchers to the Indonesian Language teacher at 2 Yogyakarta State Vocational School got the result that the tetralogy of 
Laskar Pelangi could be implemented as the alternative materials for Indonesian Language subject of Vocational School especially for the twelfth grade students.

Moreover, the tetralogy of Laskar Pelangi by Andrea Hirata contained of the genres of figurative language and rhetoric structure that could become the materials for the Indonesian language subject at Vocational School especially for the twelfth grade. It also showed the functions of figurative language and rhetoric structure as the evidence of Andrea Hirata's work. The theme of the novel was education, and through the figurative language and rhetoric structure in tetralogy of Laskar Pelangi, Andrea Hirata emerged the inspirations and living spirit to the readers. He told in his story that by passion, spirit, effort, diligence, and prayer, everything that we wanted there was a way to achieve it. It was expected that this research could give the big contribution toward the development of Indonesian language learning of Vocational School.

\section{CONCLUSION}

Based on the description about the research results above, it could be gotten some conclusions, as follows. First, the genres of figurative language and rhetoric structure in tetralogy of Laskar Pelangi were the comparing figure of speech and relating figure of speech. The genres of comparing figure of speech that were found were simile, metaphor, personification, and allegory whereas the genres of relating figure of speech were metonymy and synecdoche.Therefore, the genres of the rhetoric structures were repetition, parallelism, polysyndeton, asyndeton, hyperbola, litotes, paradox and irony, rhetoric question, climax, anti-climax and antithesis. Nevertheless, simile was the figure of speech that had highest number.

Second, the figurative language and rhetoric structure in tetralogy of Laskar Pelangi by Andrea Hirata had different functions, so when they were collaborated into one, they would produce a beautiful literature work. Simile could draw the characters to make the story and background more alive, and created the harmony and cohesiveness of the story. Metaphor had a function to emerge new vocabulary, for example, Simpai Keramat that meant as loneliness. Besides, this figure of speech also used to draw the events and the characters' situation in the story. Thus, the personification made the background more alive to get the imagination and triggered other certain senses impression whereas the allegory gave colour, created aesthethics values, described and made the language real, and emphasized the content of the story so the reader could understand the story correctly.

Besides, the metonymy aimed to strengthen the certain name or merk that were influential for the characters, to make the story more alive, and to produce the real imagination since the story told by the author might be similar with the readers' environment. The synecdoche had the function to strengthen the characters' reaction toward the events faced and emerged the imagination.Moreover, the repetition could strengthen the events through stressing, confirming, and beautifying the story by emphasizing the meaning that wanted to be expressed to the reader by repeating the words or group of words. Parallelism also gave the similar contribution as the repetition did. Thus the polysyndeton got the role to emphasize and focus on the utterance through using command words whereas asyndeton also emohasized and focused on the utterance through repeating the punctuation to show the equal position. Hyperbola could emphasize the intensive meaning that wanted to be expressed by using the excessive ways to make the expression look like real, so it could raise the imagination and certain senses. Litotes emphasized on the intensive meaning that wanted to be expressed by understating the fact to have a modest attitude and kept the well manner in relationship. Thus, paradox made the problems in the story more interesting by choosing the correct language and expression to present the aesthetic effect. Irony was used to criticize and tease the characters' attitude softly to create the effects from uncommon senses. The rhetoric questions could emerge the rhetoric effects and involved the reader or listener whether rational and emotional. Climax was used to express and emphasize the idea by showing the increasing of the intensity of the climax and important events chronologically whereas the anti-climax was used to express and emphasize the idea by showing the decreasing of the intensity of the climax and important events chronologically. Antithesis strengthened the events through emphasizing, confirming, and beutifying the story by showing the opposite meaning of the words to create the aesthetics values. The functions of figurative language and rhetoric structure in tetralogy of Laskar Pelangi were the enrichment of figure of speech that had quality and quantity. They would be able to create the aesthetics values in Andrea Hirata's works.

Third, based on the identification results of the genres and functions of the figurative language and rhetoric structure in tetralogy of Laskar Pelangi by Andrea Hirata could be implemented for the novel 
materials of Indonesian language subject for the twelfth grade of Vocational School.

\section{AUTHORS' CONTRIBUTIONS}

This research had relevant implications and had positive relation. These implications would be explained, as follows.

\section{a. Theoretical implication}

Based on the explanation above, this research could enrich the qualitative descriptive research about literature especially related to stylistic analysis of figurative language and rhetoric structure in the novel. This research did an analysis toward literature work entitled Figurative Language and Rhetoric Structure in Tetralogy of Laskar Pelangi by Andrea Hirata. Furthermore, by doing this research the litterateurs would produce some works that had best quality by doing the research firstly to the readers.

b. Pedagogical implication

For educational world, this research result could be implemented in teaching and learning process as the alternative materials of novel text in Indonesian language subject for the twelfth grade of Vocational School.

c. Practical implication

This research result was expected to enrich the knowledge that related to literature research, so the other researchers could be motivated to do the similar research that could be implemented in teaching and learning in the school. This research could become consideration research to more paying attention on the media of learning in correct way to be implemented in the school.

\section{ACKNOWLEDGMENTS}

The research result of figurative language and rhetoric structure in tetralogy of Laskar Pelangi by Andrea Hirata was limited on the figure of speech and strategic structure that referred on the stylistic study. Besides, the stylistic study was used to explain the aesthetic of the using of certain language since the study was very broad such as the sound aspect, lexical, structure, figurative language, rhetoric structure, and graphology. Thereby, this research needed to be added other aspects to make the results more comprehensive to understand the stylistic study. This research could be used as the alternative materials for Indonesian language subject for the twelfth grade of Vocational school.

\section{REFERENCES}

[1] S. N. Dita, A Stylistic Analysis of Montage, 3L The Southeast Asian Journal of English Language Studies, Vol. 16, No. 2, 2010, pp. 169- 191.

http://ejournals.ukm.my/31/article/view/1002/914

[2] A. Nezam, Translation of Ellipsis as a Stylistic Feature: Hemingway's The Old Man and the Sea and Its Persian Translations, Journal of Language Teaching and Research, Vol. 3, No. 6, 2012, pp 12501257. DOI:https://doi:10.4304/jltr.3.6.1250-1257

[3] B. Sun, The Clash between the Desire and the Real World- A Stylistic Analysis of the Short Story "Thef", Journal of Language Teaching and Research ,Vol. 2, No. 6, 2011, pp 1405- 1410. DOI: https://doi:10.4304/j1tr.2.6.1405-1410

[4] A. Hirata , Laskar Pelangi, PT Bentang Pustaka, 2016.

[5] S. Zyngier, Towards A Cultural Approach to Stylistics, Centro Virtual Cervantes, CAUCE. Revista de Filologia y su Didactica, ${ }^{\circ} 24,2001$, pages.365380 .

https://cvc.cervantes.es/literatura/cauce/pdf/cauce24/ cauce24_21.pdf

[6] H. A. Bilal and A. Cheema, Stylistic Analysis of Wordsworth's Poem: "Early Spring”, Brithish Journal of Humanities and Social Sciences, Vol. 5, No. 2, 2012, pp. 2534. http://www.ajournal.co.uk/HSpdfs/HSvolume5(2)/HS Vol.5\%20(2)\%20Article\%203.pdf

[7]. B. Nurgiyantoro, Stilistika, Gadjah Mada University Press, 2014.

[8] E. Yeibo, Figurative Language and Stylistic Function in J. P. Clark- Bekederemo's Poetry, Journal of Language Teaching and Research, Vol. 3, No. 1, 2012, pp. 180-187. DOI: $\underline{\text { https://doi:10.4304/jltr.3.1.180-187 }}$

[9] F. Aghagolzade and M. Dehgan, Stylistics and Linguistic Variations in Forough Farrokhzad's Poems, Journal of Language Teaching and Research, Vol. 3, No. 5, 2012, pp. 930-939. http://academypublication.com/issues/past/jltr/vol03/0 5/14.pdf 
[10] M. E. Baroudi, A Stylistic Analysis of Honest Deceptions: The Case of "Seinfeld TV Series" Sitcom, A paper submitted to the department of English in partial fulfillment of the reuirements for the degree of license in English (Major: Linguistics) Academic year: 2019- 2020. https://arxiv.org/pdf/2104.08599

[11] R. Galita, A Pragma- Stylistic Approach On Deixix, Linguistic and Literary Broad Research and Innovation, Vol. 2, Issue 1, 2011, pp. 36- 50.

https://brain.edusoft.ro/index.php/libri/article/view/2 $\underline{04}$

[12] K. O’ Halloran, Performance stylistics: Deleuze and Guattari, poetry and (corpus) linguistics, International Journal of English Studies, Vol. 2, No. 2, 202, pp. $171-$ https://revistas.um.es/ijes/article/view/161811/14124 1

[13]. E. A. Jaafar and F. K. Hassoon, Pedagogical Stylistics as a Tool in the Classroom: An Investigation of EFL Undergraduate Students' Ability In Analyzing Poetic Language, Arab World English Journal (AWEJ), Vol. 9, No. 1, 2018, pp. 256- 267. DOI: https://dx.doi.org/10.24093/awej/vol9no1.18 